\title{
Implementation of E-Government Information System Application for Village Service
}

\author{
Mohd. Siddik ${ }^{1}$, Guntur Maha Putra ${ }^{2}, \mathrm{Akmal}^{3}$, Nuriadi Manurung ${ }^{4}$, Adi Prijuna Lubis ${ }^{5}$ \\ Sekolah Tinggi Manajemen Informatika dan Komputer Royal, Kisaran, Indonesia ${ }^{1,2,3,4,5}$
}

\{mohdsiddik@gmail.com ${ }^{1}$ \}

\begin{abstract}
The rapid development of information technology has a significant impact, especially on government offices and agencies in managing data to improve services to the public. Using technology, of course, greatly facilitates the government apparatus in processing data and reports. The government agency of Lubuk Palas Village is one of the agencies that still provides information services manually. For example, residents who want to know information about the management of community correspondence sometimes ask the surrounding community that they also do not understand. Not infrequently this raises quite complex problems such as the occurrence of communication or differences in people's understanding of receiving and understanding information. On the other hand, community knowledge about information relating to the village is also still very minimal. This is certainly not very relevant to the development of increasingly rapid technology. To that end, in order to overcome this problem, researchers will adopt an e-Government system in information services in the Lubuk Palas Village which will later be used as a means of disseminating information to the village community.
\end{abstract}

Keyword : Implementation, Government, Village

\section{Introduction}

The development of information technology that is developing very fast has a significant impact, especially on government offices and institutions. This can be seen from the increasing number of jobs completed using technology, especially computer system technology. But on the other hand, there are still some jobs that do not get a touch of technology such as information service systems that can process quantitative and qualitative data. Though the touch of technology in this information service system will be very beneficial for the public in getting information.

At this time E-Government is needed, and its use can be used to facilitate community services, increase the potential of villages to deal with changes following Law No. 11 of 2018, regarding information management and electronic transactions for the development of information technology that can be carried out optimally. One form of the use of EGovernment is in the form of a website that will be used to provide information and view data on the potential and current conditions in the government system found in the village of Bumirejo [1]. 
In the application of interconnection E-Government systems and network, structures must be considered for infrastructure readiness and interconnection between LAN networks that must be connected. In the stages of development and development of E-Government, there are 12 variants of problems in the context of the development and development of E-Government agencies. The most widely adopted are three, namely the creation of information sites, preparation of human resources, and information site socialization. While the stages of the level of internal E-Government development are divided into four namely preparation, maturation, stabilization. In general, the level is only at the preparation stage. Therefore the public cannot yet enjoy the service. In this regard, increasing the implementation of EGovernment interconnection in the future requires socialization and technical guidance in the implementation of interconnection and E-Government in the government apparatus [2].

In improving public services, the Government of the City of Yogyakarta develops the application of e-government. Implementation of e-government by the Government of the City of Yogyakarta, the Yogyakarta City Government website. In the implementation of egovernment services in the Yogyakarta City government site considered successful. This is evident from the results of an assessment conducted by PeGI which states that the Yogyakarta City Government's e-government system is ranked first. To be able to improve services, feedback from the City Government of Yogyakarta is needed, to analyze the Yogyakarta City Government's website services, the analysis uses the E-GovQual method with a total sample of 90 respondents [3].

In the face of technological change that is increasingly moving quickly, the government needs to anticipate. With the large development of the amount of data, it is necessary to implement multi-channel effectively to the platform for digital transformation for ease of managing data. The need for technology such as social media, e-participation tools generate new data models and produce large data, this is a challenge, slowing down the public service sector. An effective concept is an interaction through electronic technology. The community can improve the e-participation process to the government and this needs to be improved by. By utilizing e-government more effectively by providing interactive services for the public [4].

There has been much discussion about the failure of previous e-government projects. Generally, the reasons for project failure are related to gaps in the design results and results of reality, then project management that is not in accordance with the reality of the design. This problem shows that half of the e-governmnet projects failed, and the others had problems. Factors for the failure of this e-government project provided an inquiry into the launch of the U.S. website. Healthcare.gov. in this case it relates to the failure of the e-government project to identify gaps in checking media sources and analyzing data on social media by viewing twitter discussions. From this analysis it can be seen that e-government users give negative comments which can be interpreted as failure [5].

Bogor City has been carrying out e-Government initiatives since 2008 and has won numerous awards related to e-Government implementation until now. Therefore the city of Bogor can be a reference for other regions in implementing e-Government. The method used is a questionnaire-based survey that lists success factors from the results of previous studies. Respondents are 16 people working in the office of the Ministry of Communication and Information Technology in Bogor, especially those related to the development of eGovernment systems. The results showed that of the 55 success factors that were asked for their level of agreement, there were only 50 success factors that met the testing criteria [6].

The need for the development of public services that are integrated with technology and communication or what is commonly called e-government is very important. There are three 
main points in the implementation of e-government that are often done. First, the initiative to implement e-government is carried out by individual local governments. Second, implementing the system through regional websites that have not supported management in an effective work process. Third, there are too many local governments that identify egovernment as a local government website, so the implementation only stops at that stage, even though there are four stages that must be passed [7].

The importance of implementing e-government for transparency, accountability and better public services. The problem of the low appreciation of the public on e-government services is widely recognized by developed countries. in this case the development of an integrative research model and extending the model with technology combined with social, political and cultural constructs. This belief is based on public assessment and national culture. Testing of this model was carried out on a large scale involving 413 Jordanians. The results find strong evidence that citizens' appreciation of the use of e-government services determines a significant outcome for using e-government services [8].

This paper aims to analyze the publication of e-government implementation. Using data related to e-government research, 130 cases were collected. 130 articles analyzed 63 articles using several different articles with correlation values according to the needs of the weight analysis and meta data. These representations are presented diagrammatically and correlate across 130 publications with significant results [9].

The information system is a combination of several elements such as hardware, software, users and others that are interrelated to achieve system goals [10]-[11]. From the various studies that have been presented above it appears that the use of e-government is very important to apply. Of course this application will be very useful for improving services to the community. The government agency of Lubuk Palas Village is one of the agencies that still provides information services manually. For example, residents who want to know information about the management of community correspondence sometimes ask the surrounding community. Not infrequently this raises quite complex problems such as the occurrence of communication or differences in people's understanding in receiving and understanding information. For this reason in overcoming this problem, researchers will adopt an e-Government system in information services in Lubuk Palas Village. With the eGovernment, the authors hope to facilitate information services in Lubuk Palas Village and facilitate government officials in processing computerized data and information properly.

\section{Methodology}

The method used in this study is SDLC (System Development Life Cycle). Where the application starts from project identification, planning, design analysis, implementation, maintenance. Project Identification Stages, at this stage the identification of Information System requirements for the development of the Lubuk Palas village e-government system that was built. Project Planning \& Initialization. This stage was decided on the determination of the scope of the e-government system of the Lubuk Palas village that was built, including the specific information system project plan, the time plan, and the resource requirements.

Stages The analysis was carried out in several sub-phases, namely: First, determining the e-government system requirements, this activity was carried out jointly between analysts and users; Second, study the needs and structure of the relationships between the system's needs so that redundancy does not occur. Third, the generalization of design alternatives to suit the needs. Fourth, compare these alternatives so that they are appropriate to the cost, resources, 
and technical level. So an agreement was reached for the development process of the Lubuk Palas village e-government Information System that was built.

Design is a description of the function of the system chosen from the development of the system in independent analysis and computer platforms. In this case, it is depicted in UML format. Implementation, which is the implementation phase of the physical design of the egovernment Information System of the Lubuk Palas village that was built. The final phase of SDLC is maintenance, which is the maintenance and repair phase of the Lubuk Palas village e-government Information System that was built. The form of the concept of the SDLC method can be seen in the following figure.

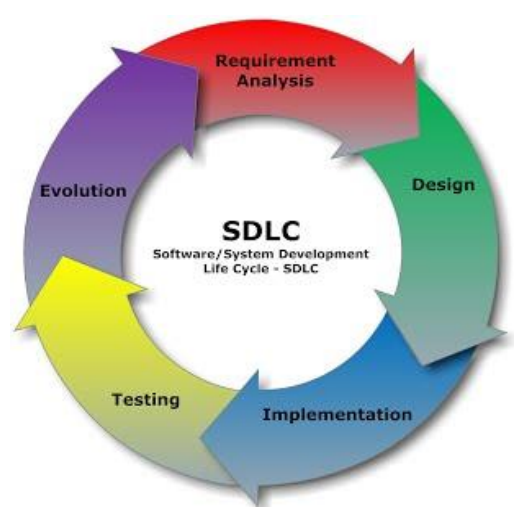

Fig. 1. System Development Life-Cycle

\section{Result and Discussion}

\subsection{System Analysis}

Seeing the ongoing population services system at the Lubuk Palas Village Head Office that still uses a simple system, it can be concluded that there are some shortcomings in the ongoing procedures, including the inefficient time spent in processing population services in serving the needs of the community starting from making certificate of domicile, certificate of introduction to E-KTP, certificate of business license, certificate of criminal record, certificate of disability. And the difficulty of getting a population report that is fast and accurate in a short time. New system to be proposed. In the following, the researchers have designed a flow diagram system that can describe the process of making a certificate starting from the visit of residents to the Lubuk Palas Village information system.

\subsection{Design}

The design of the system aims to facilitate the application of e-government information systems in Lubuk Palas Village, in which the e-Government information system will later be designed to facilitate village officials in processing activity reports in the Village and providing information services through the online system.

\subsection{Implementation and Results}


Implementation is the stage of applying and simultaneously testing the system based on the results of analysis and design into an information system in the Lubuk Palas Village which aims to provide information to the community and provide services to make a certificate file through the system. On the home, the menu displays news, activities, or information about the things that villagers need in handling the correspondence they need. On the home page, the community can also find out information about village development.

The category page on this page will be used to manage the news category, this page will later differentiate the contents of the news content that will appear on the web information system.

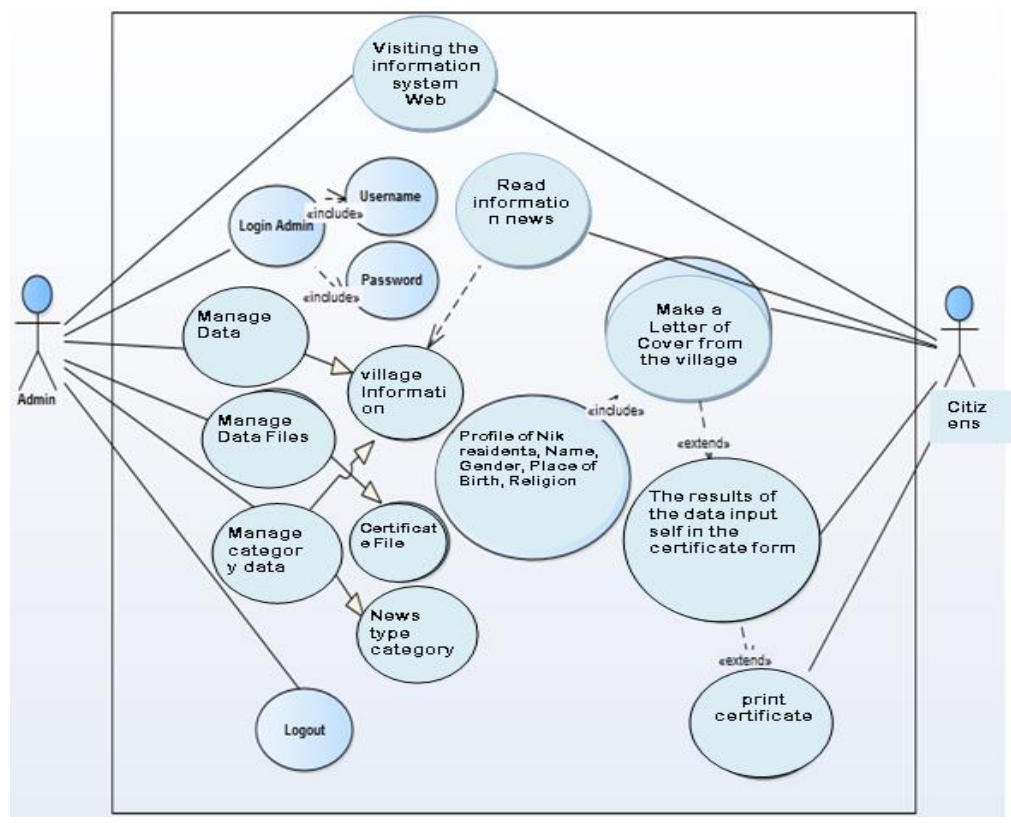

Fig. 2. System Use Case Diagram 


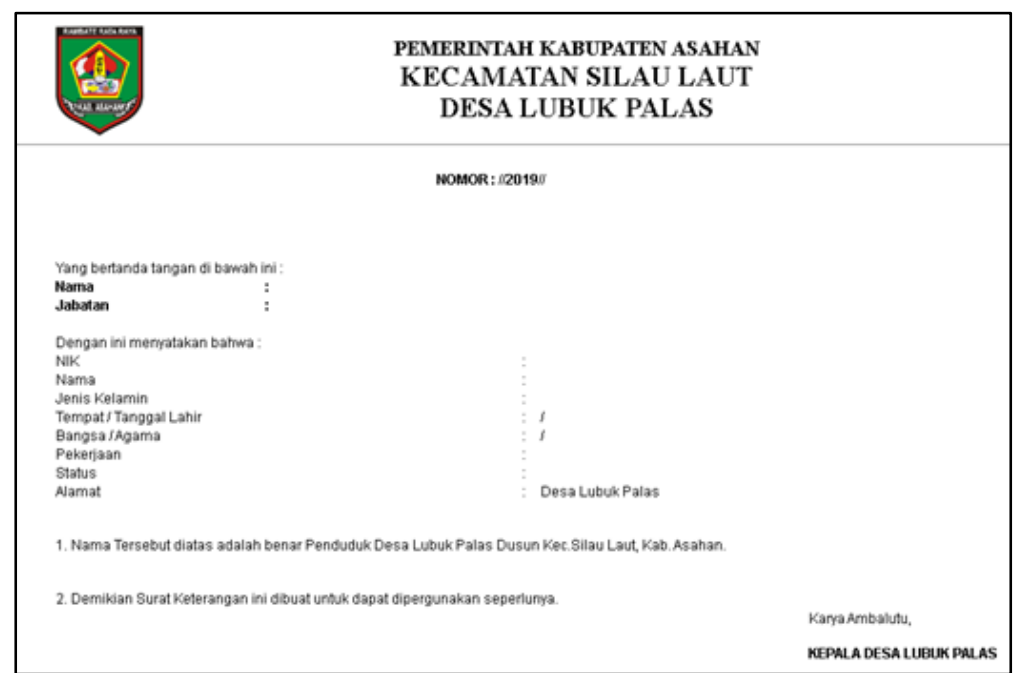

Fig. 3. Display Print Certificate of Citizens

The above display is the result of an example of issuing a citizen certificate. Later this certificate will be given to the village head, and then the village head will sign the letter.

\section{Conclusion}

Based on the results of research on the implementation of E-Government in the service information system in the Lubuk Palas Village, it can be concluded that the application that the researchers designed was aimed at the Regional Office of the Lubuk Palas Village Head. People can easily find out about every activity in the village of Lubuk Palas Village by visiting the website of the Lubuk Palas village, the Lubuk Palas Village apparatus can continue to input news and file management documents aimed at facilitating the community.

\section{References}

[1] E. Pratiwi and M. Muslihudin, "Implementasi E-Goverment Sebagai Upaya Peningkatan Potensi Desa Di Desa Bumirejo Menggunakan Web Mobile," Technol. Accept. Model, vol. 9, no. 1, pp. 22-29, 2018, [Online]. Available: www.stmikpringsewu.ac.id.

[2] A. C. Nugroho, "Interkoneksi dan Pembangunan E-Goverment Interconection and EGovernment Development," vol. 19, no. 2, pp. 209-224, 2015.

[3] P. Haryani, "Evaluasi Kualitas Layanan E-Government Pemerintah Kota Yogyakarta Dengan Metode E-GOVQUAL Modifikasi,” Simp. Nas. RAPI XV, pp. 379-386, 2016.

[4] Z. A. Al-Sai and L. M. Abualigah, "Big data and E-government: A review," ICIT 2017 - 8th Int. Conf. Inf. Technol. Proc., pp. 580-587, 2017, doi: 10.1109/ICITECH.2017.8080062.

[5] L. Anthopoulos, C. G. Reddick, I. Giannakidou, and N. Mavridis, "Why e-government projects fail? An analysis of the Healthcare.gov website," Gov. Inf. Q., vol. 33, no. 1, pp. 161-173, 2016, doi: 10.1016/j.giq.2015.07.003.

[6] D. Napitupulu, "Kajian Faktor Sukses Implementasi E-Government," J. Sist. Inf., vol. 
5, no. 3, pp. 229-236, 2009, doi: https://doi.org/10.24089/j.sisfo.2015.03.009.

[7] E. A. Sosiawan, "Tantangan Dan Hambatan Dalam Implementasi E-Government Di Indonesia,” Semin. Nas. Inform., vol. 2008, no. semnasIF, pp. 99-108, 2008.

[8] O. Al-Hujran, M. M. Al-Debei, A. Chatfield, and M. Migdadi, "The imperative of influencing citizen attitude toward e-government adoption and use," Comput. Human Behav., vol. 53, pp. 189-203, 2015, doi: 10.1016/j.chb.2015.06.025.

[9] N. P. Rana, Y. K. Dwivedi, and M. D. Williams, "A meta-analysis of existing research on citizen adoption of e-government," Inf. Syst. Front., vol. 17, no. 3, pp. 547-563, 2015, doi: 10.1007/s10796-013-9431-z.

[10] Rizaldi, D. Anggraeni, R. Rahim, A. Z. Syah, and Y. Siagian, "Decision Support System for Formula Milk Selection Based on Nutrition Value Using Tahani Model Database Fuzzy Method," J. Phys. Conf. Ser., vol. 1114, no. 1, 2018, doi: 10.1088/1742-6596/1114/1/012092.

[11] D. Anggraeni, "sistem informasi Pengelolaan Daerah Aliran Sungai Di BPDAS Kota Padang,” Jurteksi, vol. 4, no. 1, pp. 29-36, 2017, doi: 10.33330/jurteksi.v4i1.21. 